\title{
Demise of a vital resource
}

\author{
Eugene H. Blackstone, MD
}

The US Social Security Administration's (SSA) Death Master File (SSDMF) has been an important source of vital status for clinical researchers. It is sensitive and specific, ${ }^{1,2}$ reasonably up to date, and inexpensive. On November 1 , 2011, this resource disappeared as a tool for biomedical research.

\section{WHY SHOULD WE CARE?}

Active follow-up of patients after cardiothoracic surgery is costly, and the advent of restrictions on the Health Insurance Portability and Accountability Act made it even more difficult and costly for less yield. Thus, alternatives for at least vital status have been sought. The Centers for Disease Control and Prevention (CDC) National Death Index (NDI) is one such source. However, it requires a proposal, initiation and setup fees, as well as transfer of protected health information for processing at the CDC, with a variable cost per patient per year, depending on how accurate a match is specified. For even modest-sized studies, this can amount to many tens of thousands of dollars.

In contrast to the NDI, the SSDMF has been a publicly distributed resource for vital status. Centers write their own queries against the file, with no need for external requests or transfer of patient data.

Numerous publications in many medical fields have used the SSDMF, usually calling it the "Social Security Death Index" (SSDI). The Society of Thoracic Surgeons has linked its database to the SSDMF to ascertain 30-day and longer mortality information ${ }^{3}$; the Northern New England Cardiovascular Disease Study Group has used it to study the association of perioperative transfusions and longterm survival after cardiac surgery ${ }^{4}$ and of risk factors after cardiac valve surgery ${ }^{5}$; Emory University investigators have used it to study survival after hybrid coronary revascularization ${ }^{6}$ and impact of body mass index on mortality ${ }^{7}$; Northwestern University surgeons have studied perioperative statin therapy and survival ${ }^{8}$; the Cardiopulmonary Research Science and Technology Institute has used it to study reliability of risk algorithms in predicting mortality after aortic valve replacement ${ }^{9}$; and we at Cleveland Clinic have routinely used it to supplement active follow-up for

\footnotetext{
Head, Clinical Investigations, Heart and Vascular Institute, Cleveland Clinic, Cleveland, Ohio.

Disclosures: Author has nothing to disclose with regard to commercial support.

Address for reprints: Eugene H. Blackstone, MD, Cleveland Clinic, 9500 Euclid Ave/

Desk JJ-40, Cleveland, OH 44195 (E-mail: blackse@ccf.org).

J Thorac Cardiovasc Surg 2012;143:37-8

$0022-5223 / \$ 36.00$

Copyright (C) 2012 by The American Association for Thoracic Surgery

doi:10.1016/j.jtcvs.2011.11.028
}

a number of years, beginning with the study of chronic aspirin therapy and long-term survival after coronary artery bypass grafting. ${ }^{10}$

Thus, this is an important resource for understanding long-term outcomes after therapy in an efficient, inexpensive manner.

\section{WHY IS THIS HAPPENING?}

The SSDMF as distributed by the National Technical Information Service contains a mix of vital status information from federal and state sources. The SSA recently determined that death information from states cannot be redisclosed except to federal benefit-paying agencies.

Information obtained from states constitutes approximately $40 \%$ of the records. These records will be expunged from the SSDMF! This renders the SSDMF useless for biomedical research.

\section{WHAT CAN BE DONE?}

It appears that nothing can prevent the demise of this important source of vital status short of a stay while the matter is being investigated and possible alternatives put into place or swift action on the part of all states and territories. Other possibilities have been explored with the SSA, but to no avail as of this writing.

\section{IS THERE AN ALTERNATIVE?}

The NDI is more accurate than the SSDI because it uses state-reported death certificate data. However, it is 3 years behind and has been out of financial reach for most investigators for the reasons described above. Could the CDC offer an alternative to the SSDMF that could be distributed by subscription to researchers on a monthly basis, as the SSDMF is currently? It could contain the accurate NDI data known to date, supplemented by up-to-date SSA data. The latter would gradually be replaced by state data as more accurate information is received. This would make the information even more accurate than the present SSDMF and more timely than the NDI. Distribution to subscribing investigators would keep protected health information secure.

\section{WHAT CAN RESEARCHERS DO?}

I believe that only a grass-roots uprising of the biomedical community, medical societies, lobbyists, and congresspersons can save the SSDI or stimulate a CDC equivalent. Might this be one of those proverbial situations where it will take "an act of Congress?" 


\section{References}

1. Boyle CA, Decoufle P. National sources of vital status information: extent of coverage and possible selectivity in reporting. Am J Epidemiol. 1990;131: 160-8.

2. Newman TB, Brown AN. Use of commercial record linkage software and vital statistics to identify patient deaths. J Am Med Inform Assoc. 1997;4:233-7.

3. Jacobs JP, Edwards FH, Shahian DM, Prager RL, Wright CD, Puskas JD, et al. Successful linking of the Society of Thoracic Surgeons database to social security data to examine survival after cardiac operations. Ann Thorac Surg. 2011;92: 32-7; discussion 38-9.

4. Surgenor SD, Kramer RS, Olmstead EM, Ross CS, Sellke FW, Likosky DS, et al. The association of perioperative red blood cell transfusions and decreased long-term survival after cardiac surgery. Anesth Analg. 2009;108: 1741-6.

5. Leavitt BJ, Baribeau YR, DiScipio AW, Ross CS, Quinn RD, Olmstead EM, et al. Outcomes of patients undergoing concomitant aortic and mitral valve surgery in northern New England. Circulation. 2009;120:S155-62.
6. Halkos ME, Rab ST, Vassiliades TA, Morris DC, Douglas JS, Kilgo PD, et al. Hybrid coronary revascularization versus off-pump coronary artery bypass for the treatment of left main coronary stenosis. Ann Thorac Surg. 2011 Oct 12 [Epub ahead of print.].

7. Thourani VH, Keeling WB, Kilgo PD, Puskas JD, Lattouf OM, Chen EP, et al. The impact of body mass index on morbidity and short- and long-term mortality in cardiac valvular surgery. J Thorac Cardiovasc Surg. 2011;142:1052-61.

8. Vaduganathan M, Stone NJ, Lee R, McGee EC Jr, Malaisrie SC, Silverberg RA, et al. Perioperative statin therapy reduces mortality in normolipidemic patients undergoing cardiac surgery. J Thorac Cardiovasc Surg. 2010;140:1018-27.

9. Dewey TM, Brown D, Ryan WH, Herbert MA, Prince SL, Mack MJ. Reliability of risk algorithms in predicting early and late operative outcomes in high-risk patients undergoing aortic valve replacement. J Thorac Cardiovasc Surg. 2008; 135:180-7.

10. Gum PA, Thamilarasan M, Watanabe J, Blackstone EH, Lauer MS. Aspirin use and all-cause mortality among patients being evaluated for known or suspected coronary artery disease: a propensity analysis. JAMA. 2001;286:1187-94. 